\title{
Importance of multigene panel test in patients with consanguineous marriage and family history of breast cancer
}

\author{
VAHIT OZMEN $^{1}$, AHMET OKAY CAGLAYAN $^{2}$, KANAY YARARBAS $^{3}$, CETIN ORDU $^{4}$, \\ FATMA AKTEPE ${ }^{5}$, TOLGA OZMEN $^{6}$, AHMET SERKAN ILGUN $^{7}$, GURSEL SOYBIR $^{8}$, GUL ALCO $^{9}$, \\ GEORGIOS N. TSAOUSIS ${ }^{10}$, EIRINI PAPADOPOULOU ${ }^{10}$, KONSTANTINOS AGIANNITOPOULOS $^{10}$, \\ GEORGIA PEPE $^{10}$, STAVROULA KAMPOURI $^{10}$, GEORGE NASIOULAS $^{10}$, EFE SEZGIN $^{11}$ and ATILLA SORAN ${ }^{12}$ \\ ${ }^{1}$ Department of Surgery, Istanbul Faculty of Medicine, Istanbul University, Istanbul 34093; \\ ${ }^{2}$ Department of Medical Genetics, Dokuz Eylul University, Izmir 35330; Departments of ${ }^{3}$ Medical Genetics and \\ ${ }^{4}$ Medical Oncology, Demiroglu Bilim University, Istanbul 34403; ${ }^{5}$ Department of Pathology, Memorial Hospital, \\ Istanbul 34385, Turkey; ${ }^{6}$ Department of Surgery, University of Miami Miller School of Medicine, Miami, FL 33127, USA; \\ ${ }^{7}$ Department of Surgery, Demiroglu Bilim University, Istanbul 34403; ${ }^{8}$ Department of Surgery, Memorial Hospital, \\ Istanbul 34385; ${ }^{9}$ Department of Radiation Oncology, Demiroglu Bilim University, Istanbul 34403, Turkey; \\ ${ }^{10}$ Genekor Medical SA, Athens 15344, Greece; ${ }^{11}$ Department of Food Engineering, Faculty of Engineering, Izmir Institute of \\ Technology, Izmir 35430, Turkey; ${ }^{12}$ Department of Surgical Oncology, University of Pittsburgh, Pittsburgh, PA 15260, USA
}

Received July 25, 2021; Accepted January 6, 2022

DOI: $10.3892 / 01.2022 .13238$

\begin{abstract}
Next-generation sequencing (NGS) technology is used to evaluate hereditary cancer risks of patients worldwide; however, information concerning the germline multigene mutational spectrum among patients with breast cancer $(\mathrm{BC})$ with consanguineous marriage $(\mathrm{CM})$ is limited. Therefore, this prospective study aimed to determine the molecular characteristics of patients with BC who were tested with multigene hereditary cancer predisposition NGS panel and to show the effect of $\mathrm{CM}$ on cancer-related genes. Patients with $\mathrm{BC}$ with or without $\mathrm{CM}$ and family history $(\mathrm{FH})$ of $\mathrm{BC}$ treated in our breast center were selected according to The National Comprehensive Cancer Network (NCCN) criteria for hereditary BC. In these patients, the analysis of a panel of 33 genes involved in hereditary cancer predisposition was performed after genetic counseling by using NGS. The pathogenic variant $(\mathrm{PV})$ and the variant of uncertain significance (VUS) were found to be 15.8 and $47.4 \%$, respectively. PVs were identified in 10/33 genes in 34 patients; $38.2 \%$ in BRCA1/2 genes; 6,24 , and $14 \%$ in other high, moderate and low-risk genes, respectively. The CM rate was $17.7 \%$ among the 215 patients with BC. The PV rate was $13.2 \%$ in patients with $\mathrm{CM}$ and $16.4 \%$ in patients without $\mathrm{CM}(\mathrm{P}=0.80)$. When $\mathrm{PV}$ and VUS were evaluated together, the PV+VUS ratio was significantly higher in
\end{abstract}

Correspondence to: Professor Vahit Ozmen, Department of Surgery, Istanbul Faculty of Medicine, Istanbul University, Turgut Ozal Millet Cd, Istanbul 34093, Turkey

E-mail:vozmen@istanbul.edu.tr

Key words: breast cancer, consanguineous marriage, multigene testing, pathogenic variant patients with $\mathrm{CM}$ and $\mathrm{FH}$ of $\mathrm{BC}$ than patients without $\mathrm{CM}$ and FH of BC (88.2 vs. 63.3\%, $\mathrm{P}=0.045)$. Analysis of multigene panel provided $9.76 \%$ additional PVs in moderate/low-risk genes. The PV rate was similar in patients with $\mathrm{BC}$ with or without CM. A high PV+VUS ratio in patients with $\mathrm{CM}$ and $\mathrm{FH}$ of BC suggests that genes whose importance are unknown are likely to be pathogenic genes later.

\section{Introduction}

Breast cancer (BC) is the most frequently diagnosed cancer globally, with $>2$ million incident cases in 2020 (1). In Turkey, 25,345 new cases of BC were diagnosed in 2020, corresponding to $24.4 \%$ of all cancers diagnosed in women (2). Although hereditary factors contribute to $10-30 \%$ of BC pathogenesis, only a small fraction of BCs (5-10\%) can be explained by germline mutations in cancer susceptibility genes $(3,4)$, which means other susceptibility loci are likely to exist (5). Identifying unaffected disease-causing variant carriers and governing their risk has been shown to reduce $\mathrm{BC}$ and all-cause mortality (6). The selection of patients for $\mathrm{BC}$ risk assessment and counseling is mainly performed using information about the personal and/or family history $(\mathrm{FH})$ of $\mathrm{BC}$, usually following the guidelines and recommendations of The National Comprehensive Cancer Network (NCCN) (7). Although most patients with hereditary $\mathrm{BC}$ are found to have mutations in BRCA1/2 genes, it is estimated that as much as $70 \%$ of $\mathrm{BC}$ cases could be caused by mutations in other genes (8). Furthermore, recent studies have shown the importance of carefully selected patients who will benefit from genetic testing (9).

The use of multigene panel testing for detecting hereditary cancer risk has increased within the last few years, aiming to provide information and tailored management for 
more families in a convenient way regarding patients with a less typical presentation for a given cancer syndrome and/or missing FH data and to provide a cost-effective alternative to BRCA-only testing $(10,11)$.

Consanguineous marriage $(\mathrm{CM})$ is still common in various parts of the world (12) and mainly occurs as a first cousin union (13). For example, in Turkey, the prevalence of CMs is still relatively high at $20-25 \%$ (ranges from 11.5 to $46 \%)(14,15)$. However, the relationship between $\mathrm{CM}$ and BC-predisposing genes is not clear.

The present study aimed to analyze 33 genes implicated in hereditary cancer predisposition in Turkish patients with BC and investigate the impact of $\mathrm{CM}$ and $\mathrm{FH}$ of $\mathrm{BC}$ on carrying pathogenic mutations in genes associated with BC.

\section{Materials and methods}

Patients. In this prospective clinical study, patients who were treated with BC between 2018 and 2020 in our clinic were included. Patients who did not agree to participate in the study and did not have any genetic test indication were excluded. Patients were divided into two groups as CM [study group (SG)] and those without $\mathrm{CM}$ [control group $(\mathrm{CG})$ ] and were directed to genetic tests. All women received genetic counseling and psychological assistance and signed an informed consent form before molecular genetic testing and permission to use their data for research purposes. The Biruni University Ethical Committee approved the study (approval no. 2015KAEK-43-18-11; 19/09/2018). Basic demographics, personal and family histories were noted, and pedigrees were drawn by ordering clinicians (Fig. 1).

Two next-generation sequencing (NGS) multigene panels, including 26 and 33 genes related to hereditary cancer predisposition, were performed in both the SG and CG as previously described (16). The panel genes were grouped according to the associated risk for $\mathrm{BC}$ [high-risk genes, BRCA1, BRCA2, CDH1, partner and localizer of BRCA2 (PALB2), PTEN, serine/threonine-protein kinase STK11 and TP53; moderate-risk genes, serine-protein kinase ATM (ATM), serine/threonine-protein kinase Chk2 (CHEK2) and nibrin (NBN); low/unknown-risk genes, APC, bone morphogenetic protein receptor type-1A, CDK4, CDKN2A, epithelial cell adhesion molecule (EPCAM), menin, DNA mismatch repair protein Mlh1 (MLH1), DNA mismatch repair protein Msh2 (MSH2), DNA mismatch repair protein Msh6 (MSH6), adenine DNA glycosylase (MUTYH), mismatch repair endonuclease PMS2 (PMS2), proto-oncogene tyrosine-protein kinase receptor Ret, SMAD4, von Hippel-Lindau disease tumor suppressor, Fanconi anemia group J protein (BRIP1), DNA repair protein RAD51 homolog 3 (RAD51C), DNA repair protein RAD51 homolog 4 (RAD51D), BRCA1-associated RING domain protein 1 , serine/threonine-protein kinase Chk1, double-strand break repair protein MRE11, neurofibromin, DNA repair protein RAD50 (RAD50) and DNA repair protein RAD51 homolog 2] (16).

NGS and mutation confirmation. The genomic DNA was isolated from peripheral blood leukocytes according to manufacturers' protocol (Qiagen, Inc., and RBC Bioscience) and was quantified by using NanoDrop 2000c Spectrophotometer (Thermo Fisher Scientific, Inc.).

In the first protocol; a probe library (Roche NimbleGen SeqCap EZ Choice) targeting all coding exons and $50 \mathrm{bp}$ of flanking intronic regions of the 33 genes was custom-designed, and sample preparation was performed following the SeqCap EZ Choice Library User's Guide (Roche NimbleGen, Inc.) as previously described (16). Briefly, after enzymatic fragmentation (Kappa Hyperplus kit), the library was prepared according to the manufacturer's protocol (Roche NimbleGen, Inc.). NGS was performed with MiSeq Reagent Kit v3 (600-cycle) on Illumina MiSeq machine (Illumina, Inc.). Alignment to the reference sequence (hg19) and variant calling was performed by the SeqNext module of the SeqPilot suite (JSI Medical Systems GmbH).

In the second protocol; a commercially designed panel, from SOPHiA Genetics ${ }^{\mathrm{TM}}$ was used: The SOPHiA Hereditary Cancer Solutions (HCS). The library preparation was performed according to manufacturer's protocol. Sequencing was performed on Illumina Next Seq machine (Illumina, Inc.) with manufacturer's appropriate NGS kits. Alignment to the reference sequence (hg19) and variant calling was performed by the SOPHiA DDM platform of the same manufacturer.

The annotation and interpretation of all identified variants were performed using an in-house local knowledge base and a proprietary bioinformatics pipeline. The clinical significance of variants was examined using the standards and guidelines for the interpretation of sequence variants recommended by the American College of Medical Genetics and Genomics (ACMG Laboratory Quality Assurance Committee) and the Association for Molecular Pathology (AMP) (17).

All pathogenic, likely pathogenic variants (PVs) obtained from the custom designed primers and VUS were confirmed by Sanger Sequencing for further segregation analysis using Applied Biosystems 3130 Genetic Analyzer (Thermo Fisher Scientific, Inc.). Sanger sequences are presented in Figs. S1-S6. Family segregations were performed by Sanger Sequencing for further segregation analysis also using Applied Biosystems 3130 Genetic Analyzer (Thermo Fisher Scientific, Inc.).

Analysis of large genomic rearrangements (LGRs). The copy number variation (CNV) module of the software suite SeqPilot (JSI Medical Systems GmbH) and panels. MOPS (18) was used for the computational analysis of LGRs from NGS data for the following genes/gene regions, including BRCA1, BRCA2, CHEK2, EPCAM (Exons 8, 9), MLH1, MSH2, MSH6, MUTYH, PALB2, RAD50 (Exons 1, 2, 4, 10, 14, 21, 23 and 25), RAD51C, RAD51D, and TP53. All predicted LGRs detected with these algorithms were then experimentally studied using the Multiplex Ligation-dependent Probe Amplification technique as described previously $(16,18)$.

Statistical analysis. Pearson correlation analysis with ' $\mathrm{N}-1$ ' correction was performed to correlate two parameters. In addition, chi-square tests were conducted to compare the distribution of categorical variables. Fischer's exact test was used when chi-square tests assumptions did not hold due to low expected cell counts, All analyses were performed with $\mathrm{R}$ software version 3.4.4. All statistical tests were two-sided, 
Table I. Overall characteristics and test results in two groups.

\begin{tabular}{|c|c|c|c|c|}
\hline \multirow[b]{2}{*}{ Characteristic } & \multirow{2}{*}{$\begin{array}{l}\text { Patients with } \\
\text { BC }\end{array}$} & \multicolumn{2}{|c|}{ Groups } & \multirow[b]{2}{*}{ P-value } \\
\hline & & SG & CG & \\
\hline Total patients & $215^{\mathrm{a}}$ & $38(17.7)^{\mathrm{b}}$ & $177(82.3)^{\mathrm{b}}$ & \\
\hline Age at testing, years & & & & 0.3173 \\
\hline Mean \pm SD & $47.5 \pm 10.6$ & $47.4 \pm 9.9$ & $47.5 \pm 11.0$ & \\
\hline Median, range & $47(27-76)$ & $47(32-68)$ & $47(27-76)$ & \\
\hline \multicolumn{5}{|l|}{ FH of cancer, $\mathrm{n}(\%)$} \\
\hline None & $29(13.4)$ & $4(10.5)$ & $25(14.1)$ & 0.7900 \\
\hline $\mathrm{FH}$ of $\mathrm{BC}$ & 107 (49.7) & $17(44.7)$ & $90(50.8)$ & 0.5900 \\
\hline FH of other cancer(s) & $79(36.7)$ & $17(44.7)$ & $62(35.0)$ & 0.2700 \\
\hline \multicolumn{5}{|l|}{ Multigene test result, $\mathrm{n}(\%)$} \\
\hline Negative & $79(36.7)$ & $13(34.2)$ & $66(37.3)$ & 0.8500 \\
\hline Positive & $34(15.8)$ & $5(13.2)$ & $29(16.4)$ & 0.8000 \\
\hline VUS only & $102(47.4)$ & $20(52.6)$ & $82(46.3)$ & 0.5900 \\
\hline \multicolumn{5}{|l|}{ Positive in gene categories, $\mathrm{n}(\%)$} \\
\hline $\begin{array}{l}\text { NCCN absolute risk category } \\
>60 \%\end{array}$ & $13(37.1)$ & $1(20.0)$ & $12(41.4)$ & 0.6200 \\
\hline $\begin{array}{l}\text { NCCN absolute risk category } \\
41-60 \%\end{array}$ & $2(0.5)$ & 0 & $2(6.9)$ & 1.0000 \\
\hline $\begin{array}{l}\text { NCCN absolute risk category } \\
15-40 \% \text { and low/unknown risk }\end{array}$ & $19(55.8)$ & $4(80.0)$ & $15(51.7)$ & 0.6200 \\
\hline
\end{tabular}

${ }^{a}$ Data are presented as the $\mathrm{n}$; b data are presented as the $\mathrm{n}(\%)$. BC, breast cancer; $\mathrm{FH}$, family history; SG, study group; CG, control group; VUS, variant of uncertain significance; NCCN, The National Comprehensive Cancer Network.

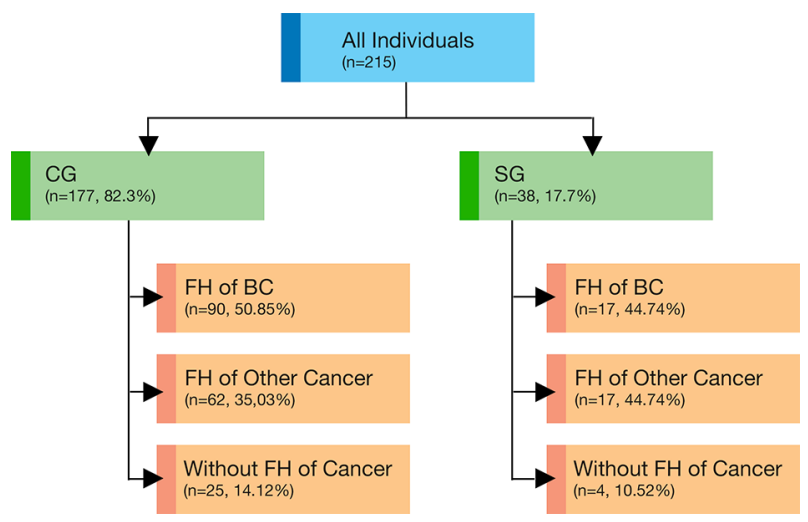

Figure 1. Study design and tested population groups and subgroups. FH, family history; BC, breast cancer; SG, study group; CG, control group.

$\mathrm{P}<0.05$ was considered to indicate a statistically significant difference.

\section{Results}

Patient characteristics. A total of 38 patients with $\mathrm{BC}$ with $\mathrm{CM}$ (SG) and 177 patients with BC without CM (CG) were referred for testing. The detailed demographic and clinical features were summarized and compared in Table I. The median age of patients was 47 years (27-76 years). The median time from diagnosis to testing was 1 year, and $67 \%$ (144/215) of patients tested within 12 months following the diagnosis. A family history $(\mathrm{FH})$ of cancer constituted a primary reason for referral, accounting for $86.4 \%(186 / 215)$. Almost half of women $(49.7 \%, 107 / 215)$ reported $\mathrm{FH}$ of BC (44.7\% in SG and 50.8\% in CG). CM was reported in $17.7 \%$ $(38 / 215)$ of the patients. There were no statistically significant differences in the patient characteristics between the two groups (Tables I-III).

Multigene panel testing results. Identified pathogenic variants (PVs) were in 10/33 genes in 34 patients; 38.2\% in BRCA1/2 genes; 6, 24 and, 14.3\% in other high, moderate, and low-risk genes, respectively (Table II). Specifically, the positive rate was 13.2 and $16.4 \%$ in the $\mathrm{SG}$ and the $\mathrm{CG}$, respectively $(\mathrm{P}=0.80$; Table I and Fig. 2).

The distribution of PV in all patients was as follows: BRCA1 (14\%), ATM (15\%), MUTYH (15\%), BRCA2 (23\%), CHECK 2 (9\%), RAD51C (9\%), PALBB2 (6\%), RAD50 (3\%), PMS2 (3\%) and EPCAM (3\%) (Table IV and Fig. 3A). There were five PVs in the SG (BRCA2, CHECK2, RAD51C, and MUTYH) and 29 PVs in the CG, respectively (Table IV and Fig. 3B and C). Variants classified as pathogenic or likely pathogenic were small deletions and insertions, missense, and splice site variants with decreasing frequency (Table IV).

The incidence of PV in FH of BC was slightly higher in the SG (29.4 vs. $23.3 \%, \mathrm{P}=0.51$; Tables II and III). Variants 
Table II. Multigene panel testing results among the categories of tested individuals.

\begin{tabular}{|c|c|c|c|c|c|c|c|}
\hline \multirow[b]{2}{*}{ Individuals } & \multirow[b]{2}{*}{$\mathrm{N}$} & \multirow[b]{2}{*}{ Positive, $\%$} & \multicolumn{4}{|c|}{ Positive in gene categories } & \multirow[b]{2}{*}{ VUS, \% } \\
\hline & & & $\begin{array}{l}\text { BRCA1 and } \\
\text { BRCA } 2, \%\end{array}$ & $\begin{array}{l}\text { Other high- } \\
\text { risk }^{\mathrm{a}}, \%\end{array}$ & $\begin{array}{l}\text { Moderate } \\
\text { risk }^{\mathrm{b}}, \%\end{array}$ & $\begin{array}{c}\text { Low/unknown } \\
\text { risk }^{\mathrm{c}}, \%\end{array}$ & \\
\hline Total individuals & 215 & 15.8 & 6.0 & 0.9 & 3.7 & 2.2 & 47.4 \\
\hline SG & 38 & 13.2 & 2.6 & 0.0 & 5.2 & 5.2 & 52.6 \\
\hline $\mathrm{CG}$ & 177 & 16.4 & 6.7 & 1.1 & 3.3 & 5.0 & 46.3 \\
\hline FH of BC & 107 & 24.3 & 10.2 & 0.9 & 4.6 & 8.4 & 21.4 \\
\hline SG & 17 & 29.4 & 5.8 & 0.0 & 11.7 & 11.7 & 58.8 \\
\hline $\mathrm{CG}$ & 90 & 23.3 & 12.2 & 1.1 & 3.3 & 7.7 & 40.0 \\
\hline FH of any cancer & 187 & 17.1 & 6.9 & 1.0 & 3.7 & 5.3 & 46.5 \\
\hline SG & 34 & 14.7 & 2.9 & 0.0 & 5.8 & 5.8 & 55.9 \\
\hline $\mathrm{CG}$ & 153 & 17.6 & 7.8 & 1.3 & 3.2 & 5.2 & 44.6 \\
\hline
\end{tabular}

${ }^{\mathrm{a} C D H 1}$, PALB2, PTEN, STK11, TP53; ' $\mathrm{ATM}, \mathrm{CHEK} 2, \mathrm{NBN} ;{ }^{\mathrm{c} A P C}, \mathrm{BMPR} 1 \mathrm{~A}, \mathrm{CDK} 4, \mathrm{CDKN} 2 \mathrm{~A}, \mathrm{EPCAM}, \mathrm{MEN} 1, \mathrm{MLH} 1, \mathrm{MSH} 2, \mathrm{MSH} 6$, MUTYH, PMS2, RET, SMAD4, VHL, BRIP1, RAD51C, RAD51D, BARD1, CHEK1, MRE11 (MRE11A), NF1, RAD50, RAD51B. BC, breast cancer; FH, family history; SG, study group; CG, control group; VUS, variant of uncertain significance; PALB2, partner and localizer of BRCA2; STK11, serine/threonine-protein kinase STK11; ATM, serine-protein kinase ATM; CHEK2, serine/threonine-protein kinase Chk2; NBN, nibrin; BMPR1A, bone morphogenetic protein receptor type-1A; EPCAM, epithelial cell adhesion molecule; MEN1, menin; MLH1, DNA mismatch repair protein Mlh1; MSH2, DNA mismatch repair protein Msh2; MSH6, DNA mismatch repair protein Msh6; MUTYH, adenine DNA glycosylase; PMS2, mismatch repair endonuclease PMS2; RET, proto-oncogene tyrosine-protein kinase receptor Ret; VHL, von Hippel-Lindau disease tumor suppressor; BARD1, BRCA1-associated RING domain protein 1; CHEK1, serine/threonine-protein kinase Chk1; MRE11, double-strand break repair protein MRE11; NF1, neurofibromin; RAD50, DNA repair protein RAD50; RAD51B, DNA repair protein RAD51 homolog 2.

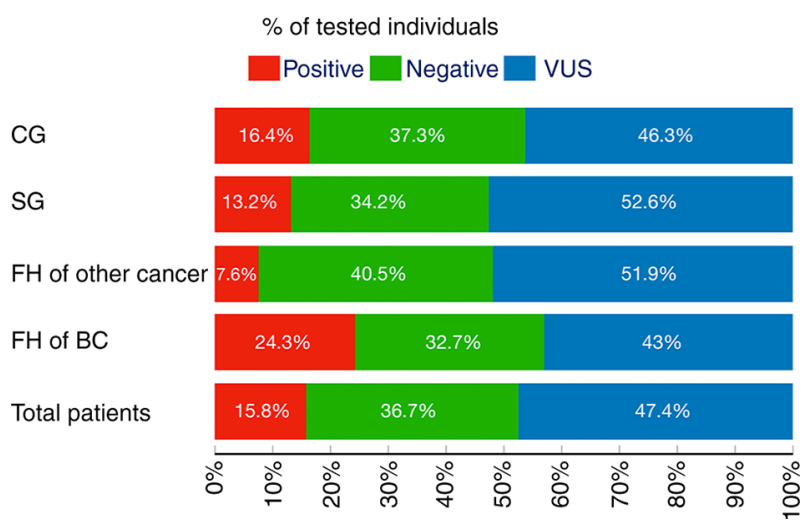

Figure 2. Multigene testing results for all groups and their subgroups according to $\mathrm{FH}$ of $\mathrm{BC}$ and other cancers and consanguineous marriage status. FH, family history; BC, breast cancer; SG, study group; CG, control group; VUS, variant of uncertain significance.

with uncertain significance (VUS) were identified in $47.4 \%$ of women. The VUS rates ranged from 21.4 to $55.9 \%$ (Table II). Among the women with a PV, 38.2\% of them had BRCA1/2 gene mutations. The high mutation frequency of the BRCA1/2 genes was $19.6 \%$ in the SG and $40.8 \%$ in the $\mathrm{CG}$, respectively $(\mathrm{P}=0.48)$. In addition, distributions of $\mathrm{PVs}$ in patients were identified in other high- $(6 \%$,$) , moderate$ (24\%) or low risk (14.3\%) genes apart from the BRCA1/2 genes, PVs were identified in CHEK2, ATM, NBN, PALB2, RAD50, RAD51C and MUTYH (monoallelic) (Fig. 3A and Table IV).
The negative genetic test result was significantly higher in those in the SG who did not have FH of BC (84.6 vs. $50 \%$, $\mathrm{P}=0.022$; Table III). However, when only patients with $\mathrm{FH}$ of BC were considered, the total PV and VUS rates were significantly higher in the SG compared with the CG (88.2 vs. $63.3 \%$, $\mathrm{P}=0.045$; Table III).

\section{Discussion}

Consanguineous marriage (CM) between biological relatives is a social custom with a long history in various parts of the world (12). Today, hundreds of millions of individuals live in consanguineous families (12-14). The offspring of consanguineous parents are more likely to have the same two alleles (homozygosity) by descent. The prevalence of CM is still relatively high at $20-25 \%$ (ranges from 11.5 to $46 \%$ ) $(14,15$ ) in Turkey. However, the relationship between $\mathrm{CM}$ and $\mathrm{BC}$-predisposing genes is not clear. In this prospective clinical study, the effect of CM on cancer-related genes in patients with $\mathrm{BC}$ was investigated.

The rate of pathogenic variants (PVs) identified with multigene NGS panel testing in Turkish patients with BC was $15.8 \%$ in our study. Most of these PVs were BRCA1 and BRCA2 genes $(\sim 39 \%)$, which is consistent with previous literature $(16,19)$. Furthermore, the prevalence of BRCA1/2 mutations in the CG was $6.7 \%$ and in those with $\mathrm{FH}$ of $\mathrm{BC}$ was $14.1 \%$, which was similar to the literature in which the prevalence ranges from 9 to $21 \%(20-22)$.

Analysis of positive gene mutations showed that more than half of the patients with $\mathrm{BC}(61.8 \%)$ having a PV would have been 
Table III. Association between FH of BC and genetic test results.

\begin{tabular}{|c|c|c|c|c|}
\hline \multirow{2}{*}{$\begin{array}{l}\text { Genetic test } \\
\text { results }\end{array}$} & \multirow[b]{2}{*}{ FH status } & \multicolumn{2}{|c|}{ Groups } & \multirow[b]{2}{*}{ P-value } \\
\hline & & $\mathrm{CG}$ & SG & \\
\hline \multirow[t]{6}{*}{ Negative } & $\mathrm{FH}$ of $\mathrm{BC}$ & & & 0.022 \\
\hline & No & $33(50.0)$ & $11(84.6)$ & \\
\hline & Yes & $33(50.0)$ & $2(15.4)$ & \\
\hline & FH of any cancer & & & 0.370 \\
\hline & No & $8(12.0)$ & $3(23.0)$ & \\
\hline & Yes & $58(88.0)$ & $10(77.0)$ & \\
\hline \multirow[t]{6}{*}{ VUS } & $\mathrm{FH}$ of $\mathrm{BC}$ & & & 0.620 \\
\hline & No & $46(56.1)$ & $10(50.0)$ & \\
\hline & Yes & $36(43.9)$ & $10(50.0)$ & \\
\hline & FH of any cancer & & & 0.170 \\
\hline & No & $14(17.0)$ & $1(5.0)$ & \\
\hline & Yes & $68(83.0)$ & $19(95.0)$ & \\
\hline Negative, PV+VUS & Only patients with $\mathrm{FH}$ of $\mathrm{BC}$ & & & 0.045 \\
\hline Negative & & $33(36.7)$ & $2(11.8)$ & \\
\hline PV+VUS & & $57(63.3)$ & $15(88.2)$ & \\
\hline
\end{tabular}

Data are presented as the $\mathrm{n}(\%)$. BC, breast cancer; FH, family history; SG, study group; CG, control group; VUS, variant of uncertain significance; PV, pathogenic variant.

missed if genetic testing was restricted to BRCA1/2 or high-risk genes included in the NCCN guidelines for Genetic/Familiar high-risk assessment for breast and ovarian cancer and could enable personalized management decisions for these patients (23).

It is noteworthy that most of the variants classified as pathogenic or likely pathogenic in the current study were deleterious (variants with small deletions, insertions, and splice sites). This may be related to the fact that most missense variants remain in the VUS class upon compliance with the ACMG classification. A notable feature in the cohort of the present study was that no large deletions and duplications (CNVs) were observed. In cases where it is impossible to calculate CNVs by the NGS method, additional testing may be considered to detect pathological CNVs, especially in BRCA1 and BRCA2 genes. Thus, it is clear that VUS monitoring will continue to maintain its importance.

Our previous study analyzed genes involved in hereditary cancer predisposition using an NGS approach in 1,197 individuals from Greece, Romania, and Turkey (16). A PV was identified in 264 of the individuals (22.1\%) analyzed, while a VUS was identified in $34.8 \%$ of cases. Nevertheless, the PV rate was lower $(15.8 \%)$ and the VUS rate was higher $(43.7 \%)$ in Turkish individuals. Moreover, as a PV, the BRCA1/2 ratio was $10.1 \%$, while other high-risk, moderate-risk, and low/unknown risk ratios were $4.4,0.6$, and $1.9 \%$, respectively, for these individuals. Similar to these findings, the PV and VUS rates were 12.8 and $47.4 \%$, respectively, in the current study. This study also found similarities regarding BRCA1/2 and other high-risk, moderate-risk, and low/unknown risk ratios (Table I). There were no significant differences between the two groups regarding PV rates (Fig. 3A-C).

The Turkish public health system covered hereditary cancer predisposition gene tests on a routine basis, which has been covered by for several years. However, only two recent studies with multigene panels were performed in Turkey. The first was a multinational study, and the pathogenic/likely pathogenic mutation rate was found to be similar (15.8\%) to our study (16). In the second study conducted by Akcay et al (19), cancer susceptibility genes were analyzed in breast and colorectal cancer patients. High BC risk genes were found in $17.2 \%$ of patients and, a low $\mathrm{BC}$ risk gene in $3.9 \%$.

Due to the sample size of the present study, no LGRs were found by any of the bioinformatics approaches, which is essential to evaluate the full mutation spectrum of tested genes, especially for BRCA1/2. In Turkey, Large Genomic Rearrangements (LGRs). rates are between $1-4 \%(19,24,25)$ comparable with different populations around the world $(0.1-12.7 \%)(16,26-30)$.

The likelihood of identifying variants of uncertain significance (VUS) increases with multigene panel testing as high as $40 \%$ (31). In the current study, the VUS rate was found to be $47.4 \%$. Most VUS reclassifications involve a downgrade to a benign variant; a small proportion may be reclassified as pathogenic (32). Therefore, the VUS should not be used to guide medical management until the clinical significance of these findings is determined (33).

Multigene panel testing is a powerful tool that detects BRCA and non-BRCA germline mutations in individuals with a family history (FH) of BC. When $\mathrm{FH}$ of $\mathrm{BC}$ was used as a stratification factor among patients with $\mathrm{BC}$, almost half of women $(49.7 \%, 107 / 215)$ reported $\mathrm{FH}$ of BC $(44.7 \%$ in SG and $50.8 \%$ in $\mathrm{CG}$ ). The patients' suitability can explain this high $\mathrm{FH}$ of $\mathrm{BC}$ rate in this study for genetic testing.

In populations where CMs are prevalent, patients are at risk for homozygous/compound heterozygous germline 

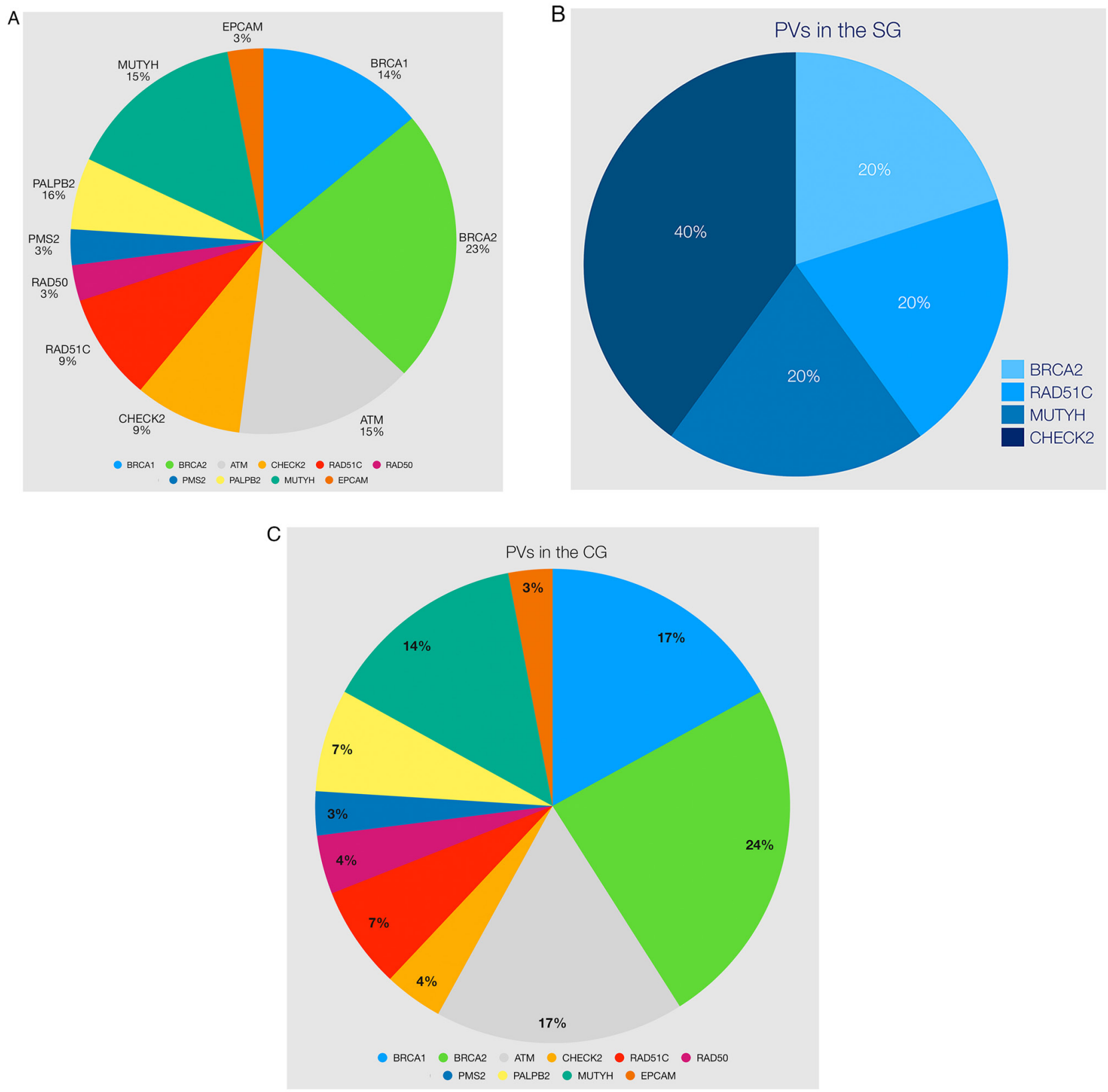

Figure 3. (A) Distribution of 34 PVs among the examined genes. (B) Distribution of five PVs in the SG. (C) Distribution of 29 PVs in the CG. PV, pathogenic variant.

mutations in BRCA2, BRIP1 and PALB2 result in Fanconi's anemia (34-36). In a previous study, the consanguinity rate in Southern Mediterranean populations was inversely correlated with families with BRCA1 germline deleterious mutations (37).

In a study by Medimegh et al (38), it was demonstrated that the parental consanguinity was protective against $\mathrm{BC}$, especially over the age of 50 . However, the results of the present study showed no significant relationships between patients with $\mathrm{BC}$ with or without $\mathrm{CM}$ and pathogenic mutations. Thus, although thousands of multigene panel tests have been performed worldwide (39), there is still an important fraction of $\mathrm{BC}$ cases that remain undiagnosed, underlying the predisposition to $\mathrm{BC}(40)$.

In a retrospective review of the multi-institutional tumor registry, including 2,237 patients with BC, 509 (60.7\%) had negative results, $108(12.8 \%)$ had deleterious mutations and
$221(26.3 \%)$ had VUS (41). In the present study, $15.8 \%$ of the patients had PVs, $47.4 \%$ had VUS and $36.7 \%$ had negative results. The PV rate did not differ between the two groups (13.2 and $16.4 \%$ in SG and CG, respectively), and the VUS rate was higher in the CM group (52.6 vs. $46.3 \%$ in the $\mathrm{SG}$ and $\mathrm{CG}$, respectively, $\mathrm{P}=0.59)$. However, when the sum of $\mathrm{PV}$ and VUS results in patients with $\mathrm{FH}$ of $\mathrm{BC}$ in two groups were compared, it was found that the sum of PV and VUS was significantly higher in the SG (63.3 vs. $88.2 \%$ in the CG and $\mathrm{SG}$, respectively, $\mathrm{P}=0.045)$. This significant result may suggest that genes of unknown importance in VUS may be important in the future.

In conclusion, the present study demonstrated the importance of using multigene panels in a multi-ethnic population and contributed to the knowledge of hereditary BC in Turkey. The pathogenic mutation rate was $24.3 \%$ in patients with $\mathrm{FH}$ 
Table IV. List of PVs/LPVs identified in this study.

\begin{tabular}{|c|c|c|c|c|}
\hline Variant & $\begin{array}{c}\text { Clinical } \\
\text { significance }\end{array}$ & $\begin{array}{l}\text { Personal history } \\
\text { of cancer }\end{array}$ & FH of cancer & $\begin{array}{c}\mathrm{CM} \\
\text { status }\end{array}$ \\
\hline $\begin{array}{l}\text { NM_007194(CHEK2): } \\
\text { c.1427C>T,p. (Thr476Met) }\end{array}$ & LPV & Breast & Breast, colon & Yes \\
\hline $\begin{array}{l}\text { NM_007194(CHEK2): } \\
\text { c.1427C>T,p. (Thr476Met) }\end{array}$ & LPV & Breast & $\begin{array}{l}\text { Breast, colorectal, } \\
\text { kidney }\end{array}$ & \\
\hline $\begin{array}{l}\text { NM_001128425(MUTYH): } \\
\text { c.1171C>T,p. }\left(\mathrm{Gln} 391^{*}\right)\end{array}$ & PV (monoallelic) & Breast & Breast & Yes \\
\hline $\begin{array}{l}\text { NM_007294(BRCA1): } \\
\text { c.4035delA,p. (Glu1346Lysfs*20) }\end{array}$ & PV & Breast & Breast, lung & Yes \\
\hline $\begin{array}{l}\text { NM_000059(BRCA2): } \\
\text { c.9682delA, p. (Ser3228Valfs*21) }\end{array}$ & PV & Breast & Breast, ovarian & No \\
\hline $\begin{array}{l}\text { NM_000059(BRCA2): } \\
\text { c.8087T>A, p. }(\text { Leu2696*) }\end{array}$ & PV & Breast & $\begin{array}{l}\text { Breast, prostate, } \\
\text { lung, gastric }\end{array}$ & No \\
\hline $\begin{array}{l}\text { NM_024675(PALB2): } \\
\text { c.3271C>T,p. }\left(\mathrm{G} \ln 1091^{*}\right)\end{array}$ & PV & Breast & Breast & No \\
\hline $\begin{array}{l}\text { NM_000059(BRCA2): } \\
\text { c.5557dupT, p. }(\text { Cys1853Leufs*5) }\end{array}$ & PV & Breast & Breast & No \\
\hline $\begin{array}{l}\text { NM_007294(BRCA1): } \\
\text { c.5266dupC,p. }(\text { Gln 1756Profs*74) }\end{array}$ & PV & Breast & $\begin{array}{l}\text { Breast, gastric, } \\
\text { skin, lung }\end{array}$ & No \\
\hline $\begin{array}{l}\text { NM_058216(RAD51C }): \\
\text { c. } 904+5 \mathrm{G}>\mathrm{T}\end{array}$ & LPV & $\begin{array}{l}\text { Breast, } \\
\text { ovarian }\end{array}$ & $\begin{array}{l}\text { Breast, ovarian } \\
\text { prostate }\end{array}$ & , No \\
\hline $\begin{array}{l}\text { NM_000051(ATM):c.6527delT, p. } \\
(\text { Leu2176Cysfs*59) }\end{array}$ & PV & Breast & $\begin{array}{l}\text { Breast, lung, } \\
\text { uterine }\end{array}$ & No \\
\hline $\begin{array}{l}\text { NM_007294(BRCA1): } \\
\text { c.3700_3704delGTAAA, p. } \\
\text { (Val1234Glnfs*8) }\end{array}$ & PV & Breast & $\begin{array}{l}\text { Breast, skin, } \\
\text { melanoma, } \\
\text { uterine }\end{array}$ & No \\
\hline $\begin{array}{l}\text { NM_005732(RAD50): } \\
\text { c.326_329delCAGA,p. (Thr109Asnfs*20) }\end{array}$ & PV & Breast & $\begin{array}{l}\text { Breast, skin, } \\
\text { melanoma, uterine }\end{array}$ & No \\
\hline $\begin{array}{l}\text { NM_002485(NBN): c.657_661delACAAA, } \\
\text { p. (Lys219Asnfs*16) }\end{array}$ & PV & Breast & lymphoma & No \\
\hline $\begin{array}{l}\text { NM_007194(CHEK2):c.1427C>T,p. } \\
\text { (Thr476Met) }\end{array}$ & LPV & Breast & None & No \\
\hline $\begin{array}{l}\text { NM_001128425(MUTYH):c.884C>T,p. } \\
\text { (Pro295Leu) }\end{array}$ & PV (monoallelic) & None & Pancreatic & NA \\
\hline $\begin{array}{l}\text { NM_000059(BRCA2): } \\
\text { c.4936_4939delGAAA, p.Glu1646Glnfs*23 }\end{array}$ & PV & None & Breast, ovarian & NA \\
\hline NM_000179(MSH6):c.2764C>T, p.(Arg922*) & PV & None & Breast, intestine & NA \\
\hline NM_007194(CHEK2):c.793-1G>A & PV & None & Breast, ovarian, lung & NA \\
\hline NM_001128425.1(MUTYH):c.1187G>A & LPV & Breast & No & No \\
\hline NM_002878.3(RAD51D):c.480+1G >A & PV & Breast & Breast & Yes \\
\hline NM_000059.3(BRCA2):c.8940delA & PV & Breast & Prostate, lung & No \\
\hline NM_007294.4(BRCA1):c.1621C>T & PV & Breast & Breast, ovarian & No \\
\hline NM_000051.3(ATM):c.2922-2A>G & PV & Breast & Pancreas, lung & No \\
\hline NM_000059.3(BRCA2): c.2307dupT & PV & Breast & Colon & No \\
\hline NM_000059.3(BRCA2):c.5073dupA & PV & Breast & Breast, prostate & Yes \\
\hline $\begin{array}{l}\text { NM_001128425.1(MUTYH): } \\
\text { c.1437_1439delGGA }\end{array}$ & PV & Breast & Breast, colon & No \\
\hline NM_000051.3(ATM):c.2284_2285delCT & PV & Breast & Breast & No \\
\hline NM_058216.3(RAD51C):c.181_182delCT & PV & Breast & No & No \\
\hline NM_000051.3(ATM):c.6527delT & PV & Breast & Breast & No \\
\hline NM_024675.4(PALB2):c.932_933insC & PV & Breast & Lung & No \\
\hline NM_000535.7(PMS2):c.988+1del & PV & Breast & Breast & No \\
\hline
\end{tabular}


Table IV. Continued.

\begin{tabular}{|c|c|c|c|c|}
\hline Variant & $\begin{array}{c}\text { Clinical } \\
\text { significance }\end{array}$ & $\begin{array}{l}\text { Personal history } \\
\text { of cancer }\end{array}$ & FH of cancer & $\begin{array}{c}\mathrm{CM} \\
\text { status }\end{array}$ \\
\hline NM_000314.8(PTEN):c.93delC & LPV & Breast & Breast, gastric, prostate, lung & No \\
\hline NM_005732.4(RAD50):c.1873delT & LPV & Breast & Breast, gastric, prostate, lung & No \\
\hline NM_007294.4(BRCA1):c.5266dupC & PV & Breast & Breast, ovarian, lung & No \\
\hline NM_000051.3(ATM):c.3576G>A & PV & Breast & NA & NA \\
\hline NM_000059.3(BRCA2):c.4376dupA & LPV & Breast & Breast, ovarian, endometrium & No \\
\hline NM_002354.2(EPCAM):c.556-14A>G & PV & Breast & Breast, gastric & No \\
\hline $\begin{array}{l}\text { NM_000059.3(BRCA2):rsa13q13.1 } \\
\text { (BRCA2exon3)x1 }\end{array}$ & LPV & Breast & Breast & No \\
\hline NM_007294.4(BRCA1):c.5176A>T & PV & Breast & Breast, ovarian, CNS & No \\
\hline NM_001128425.1(MUTYH):c.1187G>A & PV & Breast & Colon, lung & No \\
\hline NM_001128425.1(MUTYH):c.734G >A & PV & Breast & Breast & No \\
\hline
\end{tabular}

LPV, likely pathogenic variants; PV, pathogenic variants; CNS, central nervous system; FH, family history; CM, consanguineous marriage; $\mathrm{PV}$, pathogenic variant; NA, no available information.

of BC. The PV rate in patients with $\mathrm{FH}$ of $\mathrm{BC}$ reached $29.4 \%$ in the SG. Therefore, multigene panel testing should be considered for these patients. The CM did not significantly increase the pathogenic mutation rate, but the VUS rate was higher in this group. This observation should be confirmed with further prospective clinical trials with more extensive series.

\section{Acknowledgements}

Not applicable.

\section{Funding}

No funding was received.

\section{Availability of data and materials}

The datasets generated and/or analyzed during the current study are available in the ClinVar respiratory, ncbi.nlm. nih.gov/clinvar/?term=SUB10439877 and ncbi.nlm.nih. gov/clinvar/?term=SUB10447902

\section{Authors' contributions}

GNT, EP and AS drafted the manuscript. GNT performed bioinformatics and statistical analysis, analyzed and interpreted the variant data and prepared all supporting materials and figures. AOC, EP, KA, GP, SK and KY designed the study and experiments, collected the demographic data, and coordinated the study and all mutational analyses. GNT, EP, KA, GP, SK, GN, VO, TO, KY and AOC participated in the writing of the manuscript, performed DNA extraction, sequencing and Multiplex Ligation-dependent Probe Amplification experiments, and contributed to the analysis and interpretation of the variant data. VO, AOC, KY, CO, FA, TO, ASI, GS, GA, GNT, EP, KA, GP, SK, GN, ES and AS provided the patient material, diagnosis and management. VO, TO and AS conceived the study and participated in its design and coordination. GNT and KY confirm the authenticity of all raw data. All authors have read and approved the final manuscript.

\section{Ethics approval and consent to participate}

All tested individuals provided signed informed consent form before molecular genetic testing and permission for the anonymous use of their data for research purposes and/or scientific publications. The study was approved by The Biruni University Ethical Committee (approval no. 2015-KAEK-43-1 8-11; date, 19/09/2018).

\section{Patient consent for publication}

Present within informed consent forms.

\section{Competing interests}

The authors declare that they have no competing interests.

\section{References}

1. Ferlay J, Colombet M, Soerjomataram I, Parkin DM, Piñeros M, Znaor A and Bray F: Cancer statistics for the year 2020: An overview. Int J Cancer 149: 778-789, 2021.

2. Ferlay J, Ervik M, Lam F, Colombet M, Mery L, Piñeros M, Znaor A, Soerjomataram I and Bray F (2018): Global cancer observatory: Cancer today. Lyon, France: International Agency for Research on Cancer. Available from: https://gco.iarc.fr/today, accessed [28 May 2019].

3. Newman B, Austin MA, Lee M and King MC: Inheritance of human breast cancer: evidence for autosomal dominant transmission in high-risk families. Proc Natl Acad Sci USA 85: 3044-3048, 1988.

4. Claus EB, Risch N and Thompson WD: Genetic analysis of breast cancer in the cancer and steroid hormone study. Am J Hum Genet 48: 232-242, 1991. 
5. Walsh T and King MC: Ten genes for inherited breast cancer Cancer Cell 11: 103-105, 2007.

6. Domchek SM, Friebel TM, Singer CF, Evans DG, Lynch HT, Isaacs C, Garber JE, Neuhausen SL, Matloff E, Eeles R, et al: Association of risk-reducing surgery in BRCA1 or BRCA2 mutation carriers with cancer risk and mortality. JAMA 304: 967-975, 2010.

7. The National Comprehensive Cancer Network. https://www. nccn.org. Accessed 30 October, 2020.

8. Valencia OM, Samuel SE, Viscusi RK, Riall TS, Neumayer LA and Aziz $\mathrm{H}$ : The role of genetic testing in patients with breast cancer: A review. JAMA Surg 152: 589-94. 2017.

9. Beitsch PD, Whitworth PW, Hughes K, Patel R, Rosen B, Compagnoni G, Baron P, Simmons R, Smith LA, Grady I, et al: Underdiagnosis of hereditary breast cancer: Are genetic testing guidelines a tool or an obstacle? J Clin Oncol 37: 453-460, 2019.

10. Asphaug L and Melberg HO: The cost-effectiveness of multigene panel testing for hereditary breast and ovarian cancer in Norway. MDM Policy Pract: Feb 1, 2019 (Epub ahead of print). doi: $10.1177 / 2381468318821103$.

11. Stanislaw C, Xue Y and Wilcox WR: Genetic evaluation and testing for hereditary forms of cancer in the era of next-generation sequencing. Cancer Biol Med 13: 55-67, 2016.

12. Romeo $\mathrm{G}$ and Bittles $\mathrm{AH}$ : Consanguinity in the contemporary world. Hum Hered 77: 6-9, 2014

13. Hamamy H: Consanguineous marriages: Preconception consultation in primary health care settings. J Community Genet 3 : 185-192, 2012.

14. Alper OM, Erengin H, Manguoğlu AE, Bilgen T, Cetin Z, Dedeoğlu $\mathrm{N}$ and Lüleci G: Consanguineous marriages in the province of Antalya, Turkey. Annales de Genetique 47: 129-138, 2004.

15. Erdem $Y$ and Tekşen F: Genetic screening services provided in Turkey. J Genet Couns 22: 858-864, 2013

16. Tsaousis GN, Papadopoulou E, Apessos A, Agiannitopoulos K, Pepe G, Kampouri S, Diamantopoulos N, Floros T, Iosifidou R, Katopodi O, et al: Analysis of hereditary cancer syndromes by using a panel of genes: Novel and multiple pathogenic mutations. BMC Cancer 19: 535, 2019.

17. Richards S, Aziz N, Bale S, Bick D, Das S, Gastier-Foster J, Grody WW, Hegde M, Lyon E, Spector E, et al: Standards and guidelines for the interpretation of sequence variants: A joint consensus recommendation of the american college of medical genetics and genomics and the association for molecular pathology. Genet Med 17: 405-424, 2015.

18. Povysil G, Tzika A, Vogt J, Haunschmid V, Messiaen L, Zschocke J, Klambauer G, Hochreiter S and Wimmer K: panelen. MOPS: Copy-number detection in targeted NGS panel data for clinical diagnostics. Hum Mutat 38: 889-897, 2017.

19. Akcay IM, Celik E, Agaoglu NB, Alkurt G, Kizilboga Akgun T, Yildiz J, Enc F, Kir G, Canbek S, Kilic A, et al: Germline pathogenic variant spectrum in 25 cancer susceptibility genes in Turkish breast and colorectal cancer patients and elderly controls. Int J Cancer 148: 285-295, 2020

20. Lang GT, Shi JX, Hu X, Zhang CH, Shan L, Song CG, Zhuang ZG, Cao AY, Ling H, Yu KD, et al: The spectrum of BRCA mutations and characteristics of BRCA-associated breast cancers in China: Screening of 2,991 patients and 1,043 controls by next-generation sequencing. Int J Cancer 141: 129-142, 2017.

21. Walsh T, Casadei S, Coats KH, Swisher E, Stray SM, Higgins J, Roach KC, Mandell J, Lee MK, Ciernikova S, et al: Spectrum of mutations in BRCA1, BRCA2, CHEK2, and TP53 in families at high risk of breast cancer. JAMA 295: 1379-1388, 2006

22. Han SA, Kim SW, Kang E, Park SK, Ahn SH, Lee MH, Nam SJ, Han W, Bae YT, Kim HA, et al: The prevalence of BRCA mutations among familial breast cancer patients in Korea: Results of the Korean hereditary breast cancer study. Fam Cancer 12: 75-81, 2013

23. The National Comprehensive Cancer Network. Genetic/Familia High-Risk Assessment: Breast and Ovarian (Version 3.2019) https://www.nccn.org/professionals/physician_gls/pdf/genetics_ screening.pdf. Accessed 30 October, 2020.

24. Yazıcı H, Kılıç S, Akdeniz D, Şükrüoğlu Ö, Tuncer ŞB, Avşar M, Kuru G, Celik B, Küçücük S and Saip P: Frequency of rearrangements versus small indels mutations in BRCA1 and BRCA2 Genes in Turkish patients with high risk breast and ovarian cancer. Eur J Breast Health 14: 93-99, 2018.
25. Aktas D, Gultekin M, Kabacam S, Alikasifoglu M, Turan AT, Tulunay G, Kose MF, Ortac F, Yüce K, Tunçbilek E and Ayhan A: Identification of point mutations and large rearrangements in the BRCA1 gene in 667 Turkish unselected ovarian cancer patients. Gynecol Oncol 119: 131-135, 2010.

26. Judkins T, Rosenthal E, Arnell C, Burbidge LA, Geary W, Barrus T, Schoenberger J, Trost J, Wenstrup RJ and Roa BB: Clinical significance of large rearrangements in BRCA1 and BRCA2. Cancer 118: 5210-5216, 2012.

27. Arnold AG, Otegbeye E, Fleischut MH, Glogowski EA, Siegel B, Boyar SR, Salo-Mullen E, Amoroso K, Sheehan M, Berliner JL, et al: Assessment of individuals with BRCA1 and BRCA2 large rearrangements in high-risk breast and ovarian cancer families. Breast Cancer Res Treat 145: 625-634, 2014.

28. Casilli F, Tournier I, Sinilnikova OM, Coulet F, Soubrier F, Houdayer C, Hardouin A, Berthet P, Sobol H, Bourdon V, et al: The contribution of germline rearrangements to the spectrum of BRCA2 mutations. J Med Genet 43: e49, 2006.

29. Gonzalez-Hormazabal P, Gutierrez-Enriquez S, Gaete D Reyes JM, Peralta O, Waugh E, Gomez F, Margarit S, Bravo T, Blanco $\mathrm{R}$, et al: Spectrum of BRCA1/2 point mutations and genomic rearrangements in high-risk breast/ovarian cancer Chilean families. Breast Cancer Res Treat 126: 705-716, 2011.

30. Pylkäs K, Erkko H, Nikkilä J, Sólyom S and Winqvist R: Analysis of large deletions in BRCA1, BRCA2 and PALB2 genes in Finnish breast and ovarian cancer families. BMC Cancer 8: 146. 2008

31. Yurgelun MB, Allen B, Kaldate RR, Bowles KR, Judkins T, Kaushik P, Roa BB, Wenstrup RJ, Hartman AR and Syngal S: Identification of a variety of mutations in cancer predisposition genes in patients with suspected lynch syndrome. Gastroenterology 149: 604-613.e20, 2015.

32. Macklin S, Durand N, Atwal P and Hines S: Observed frequency and challenges of variant reclassification in a hereditary cancer clinic. Genet Med 20: 346-350, 2018.

33. Moghadasi S, Eccles DM, Devilee P, Vreeswijk MP and van Asperen CJ: Classification and clinical management of variants of uncertain significance in high penetrance cancer predisposition genes. Hum Mutat 37: 331-336, 2016.

34. Howlett NG, Taniguchi T, Olson S, Cox B, Waisfisz Q, De Die-Smulders C, Persky N, Grompe M, Joenje H, Pals G, et al: Biallelic inactivation of BRCA2 in Fanconi anemia. Science 297: 606-609, 2002

35. Levitus M, Waisfisz Q, Godthelp BC, de Vries Y, Hussain S, Wiegant WW, Elghalbzouri-Maghrani E, Steltenpool J, Rooimans MA, Pals G, et al: The DNA helicase BRIP1 is defective in Fanconi anemia complementation group J. Nat Genet 37: 934-935, 2005.

36. Reid S, Schindler D, Hanenberg H, Barker K, Hanks S, Kalb R, Neveling K, Kelly P, Seal S, Freund M, et al: Biallelic mutations in PALB2 cause Fanconi anemia subtype FA-N and predispose to childhood cancer. Nat Genet 39: 162-164, 2007.

37. Belaiba F, Medimegh I, Bidet Y, Boussetta S, Baroudi O, Mezlini A, Bignon YJ and Benammar El gaaied A: BRCA1/BRCA2 Mutations Shaped by ancient consanguinity practice in southern mediterranean populations. Asian Pac J Cancer Prev 19: 2963-2972, 2018.

38. Medimegh I, Troudi W, Omrane I, Ayari H, Uhrhummer N, Majoul H, Benayed F, Mezlini A, Bignon YJ, Sibille C and Elgaaied AB: Consanguinity protecting effect against breast cancer among tunisian women: Analysis of BRCA1 haplotypes. Asian Pac J Cancer Prev 16: 4051-4055, 2015.

39. LaDuca H, Polley EC, Yussuf A, Hoang L, Gutierrez S, Hart SN, Yadav S, Hu C, Na J, Goldgar DE, et al: A clinical guide to hereditary cancer panel testing: Evaluation of gene-specific cancer associations and sensitivity of genetic testing criteria in a cohort of 165,000 high-risk patients. Genet Med 22: 407-415, 2019.

40. Couch FJ, Nathanson KL and Offit K: Two decades after BRCA: Setting paradigms in personalized cancer care and prevention. Science 343: 1466-1470, 2014.

41. Bagwell AK, Sutton TL, Gardiner S and Johnson N: Outcomes of large panel genetic evaluation of breast cancer patients in a community-based cancer institute. Am J Surg 221: 1159-1163, 2021.

This work is licensed under a Creative Commons

Attribution-NonCommercial-NoDerivatives 4.0 International (CC BY-NC-ND 4.0) License. 